\title{
Karakteristik dan Profil Asam Lemak Minyak Ikan dari Kepala dan Tulang Ikan Tuna (Thunnus albacares)
}

\author{
The characteristics and profile of fatty acid taken from the head and bone of Tuna (Thunnus \\ albacares)
}

\section{Daniel A.N. Apituley, Raja Bonan Dolok Sormin*, Esterlina E.E.M. Nanlohy}

Jurusan Teknologi Hasil Perikanan, Fakultas Perikanan dan Ilmu Kelautan, Universitas Pattimura, Jl. Mr. Chr. Soplanit, Kampus Poka, Ambon 97233

*Penulis korespondensi: Raja B.D. Sormin, e-mail: sormin.rbd@fpik.unpatti.ac.id

Tanggal submisi: 8 Januari 2020; Tanggal penerimaan: 8 April 2020

\begin{abstract}
This study was aimed to determine the physical and chemical quality as well as the fatty acid profile of fish oil from the waste of the head and the bones of Thunnus albacares. An experimental method was applied in this research. Observed variables included yield, density, acid number, saponification value, iodine number, TBA value, as well as fatty acid profile. The results showed that the physical characteristics of the oil from the head and bone of the fish, i.e., yield $12,11 \%$ and $9.85 \%$, density $0.92 \mathrm{mg} / \mathrm{mL}$, and $0.90 \mathrm{mg} / \mathrm{mL}$, respectively. The chemical characteristics of the oil from head and bones of tuna were acid number $2.10 \mathrm{mg}$ $\mathrm{KOH} / \mathrm{g}$ and $2.88 \mathrm{mg} \mathrm{KOH} / \mathrm{g}$, iodine number $88.80 \mathrm{mg} \mathrm{KOH} / \mathrm{g}$ and $77.67 \mathrm{mg} \mathrm{KOH} / \mathrm{g}$; saponification number $178.80 \mathrm{mg} \mathrm{KOH} / \mathrm{g}$ and $145.50 \mathrm{mg} \mathrm{KOH} / \mathrm{g}$, TBA values $1.80 \mathrm{mg} \mathrm{KOH} / \mathrm{kg}$ and $1.29 \mathrm{mg} \mathrm{KOH} / \mathrm{kg}$, subsequently. Unsaturated fatty acids were found to dominate oil from the head and bones of tuna. Tuna head contained 25 types of fatty acids consisting of 10 types of saturated fatty acids (SFA) $20.8 \% \mathrm{w} / \mathrm{w}$, seven types of monounsaturated fatty acids (MUFA) $11.92 \% \mathrm{w} / \mathrm{w}$, eight polyunsaturated fatty acids (PUFA) $35.98 \% \mathrm{w} / \mathrm{w}$. In comparison, tuna bones contained 26 types of fatty acids consisting of 11 SFA $19.69 \% \mathrm{w} / \mathrm{w}$, seven MUFA $10.80 \% \mathrm{w} / \mathrm{w}$, and 8 PUFA $26.21 \% \mathrm{w} / \mathrm{w}$.
\end{abstract}

Keywords: fatty acid, fish oil, Thunnus albacares, waste of head and bone

\section{ABSTRAK}

Penelitian ini bertujuan untuk mengetahui kualitas fisik maupun kimiawi serta profil asam lemak minyak limbah ikan dari kepala dan tulang ikan tuna (Thunnus albacares). Metode yang digunakan adalah metode eksperimen. Parameter yang diamati yaitu: rendemen, berat jenis minyak, bilangan penyabunan, bilangan iodin, bilangan Tiobarbituric Acid (TBA) serta profil asam lemak. Hasil penelitian menunjukkan karakteristik fisik dari kepala dan tulang ikan berturut-turut adalah: rendemen 12,11 dan 9,85\%; berat jenis minyak $0,92 \mathrm{mg} / \mathrm{mL}$ dan $0,90 \mathrm{mg} / \mathrm{mL}$. Karakteristik kimia dari kepala dan tulang ikan tuna adalah berturutturut: bilangan asam 2,10 mg KOH/g dan 2,88 mg KOH/g; bilangan iod 88,80 mg KOH/g dan 77,67 mg $\mathrm{KOH} / \mathrm{g}$; bilangan penyabunan 178,80 mg KOH/g dan 145,50 mg KOH/g; nilai TBA $1,80 \mathrm{mg} \mathrm{KOH} / \mathrm{kg}$ dan $1,29 \mathrm{mg} \mathrm{KOH} / \mathrm{kg}$. Asam lemak tidak jenuh mendominasi minyak dari kepala maupun tulang ikan Tuna. Kepala ikan tuna mengandung 25 jenis asam lemak terdiri dari 10 jenis asam lemak jenuh (SFA) 20,8\% w/w, 7 jenis lemak tak jenuh tunggal (MUFA) 11,92\% w/w, 8 asam lemak tak jenuh jamak (PUFA) 35,98\% w/w; sedangkan tulang ikan Tuna mengandung 26 jenis asam lemak terdiri dari 11 SFA 19,69\% w/w, 7 MUFA $10,80 \% \mathrm{w} / \mathrm{w}$, dan 8 PUFA $26,21 \% \mathrm{w} / \mathrm{w}$.

Kata kunci: asam lemak, minyak ikan, Thunnus albacares, limbah tulang dan kepala 


\section{PENDAHULUAN}

Ikan tuna (Thunnus albacares) merupakan komoditas ekspor utama Indonesia. Lokasi penyebarannya di Indonesia antara lain di pada laut Barat Sumatera, Selatan Jawa, Selat Malaka, Timur Sumatera, Utara Jawa, Bali - Nusa Tenggara Timur, Kalimantan, Selatan Sulawesi, Utara Sulawesi dan Maluku - Papua. Produksi tuna terus mengalami peningkatan sejak tahun 2004 nilai produksi tuna sebesar 112.796 ton dan meningkat menjadi 167.800 ton pada tahun 2015 . Pemasaran ikan tuna dilakukan dalam bentuk produk segar atau pendinginan, fillet beku, steak beku ikan kaleng dan tuna loin (KKP, 2015). Dua decade belakangan ini Propinsi Maluku mengandalkan produk tuna loin sebagai komoditas ekspornya. Produk ini merupakan seperampat bagian tubuh ikan tuna yang telah mengalami penanganan pembuangan tulang dan duri, daging merah dan kulit. Proses produksi loin dari seekor ikan tuna menghasilkan limbah sebesar 60,3\% yang terdiri dari daging merah ("tetelan") sebesar $23,1 \%$; kepala $17,8 \%$; tulang dan sirip $8,5 \%$; kulit $3,7 \%$; isi perut/lambung (jeroan) $3,2 \%$; darah $0,9 \%$, jantung $0,6 \%$ dan lain-lain $2.5 \%$ (Kantun et al., 2014). Limbah atau hasil samping, adalah bagian yang tidak dimanfaatkan untuk diolah lebih lanjut setelah bagian yang dimakan atau dagingnya dipishkan. Tulang ikan adalah bagian yang menjadi limbah industri perikanan, sampai saat ini belum mendapatkan perhatian dari pengolah ikan. Komposisi dari tulang ikan adalah senyawa organic dan senyawa anorganik (mineral). Tulang ikan mengandung senyawa organik organik sekitar $30,54 \%$ (bk) yang terdiri dari protein $28,04 \%$, lipid $1,94 \%$ dan karbohidrat $0,56 \%$, dan bahan anorganik berupa mineral sekitar 69,49 (bk) yang terdiri dari bahan utama kalsium (Ca) dan fosfor (P) (Jung et al., 2005). Semua bagian dari ikan merupakan komponen organik yang seharusnya masih bisa dimanfaatkan sebagai sumber bahan pangan hewani.

Limbah industri perikanan selama ini belum ditangani secara optimal, limbah hanya diolah menjadi tepung ikan atau pakan ternak, selebihnya dibuang atau dibawa ke tempat pembuangan akhir. Kepala, tulang dan kulit ikan merupakan limbah hasil industri perikanan yang belum banyak dimanfaatkan dengan baik. Salah satu bentuk pemanfaatan limbah industri perikanan yang dapat dimanfaatkan adalah pengolahan yaitu minyak ikan. Telah diketahui bahwa kepala maupun tulang ikan mengandung lemak yang kaya akan vitamin A dan asam lemak omega-3 yang baik untuk kesehatan. Pengolahannya menjadi minyak ikan diharapkan dapat mengurangi produksi limbah kepala maupun tulang ikan tuna yang dihasilkan dari proses pengolahan tuna loin.

Minyak ikan mengandung omega-3, minyak ini sangat diperlukan untuk kesehatan, minyak ikan juga menganduns asam lemak essensial yang tidak dapat diproduksi secara alami oleh tubuh. Ada dua jenis asam lemak omega-3 yang terdapat dalam minyak ikan, yaitu docosahexaenoic acid (DHA) dan eicosapentaenoic acid (EPA). Minyak ikan juga mengandung vitamin $\mathrm{A}$ dan $\mathrm{D}$, dua jenis vitamin yang larut dalam lemak dengan jumlah tinggi.

Beberapa penelitian tentang minyak ikan telah dilakukan oleh banyak peneliti di beberapa negara, antara lain ektraksi minyak dari bagian kepala (Estiasih et al., 2009; Sarker et al., 2012); dari hati (Purwaningsih et al., 2014), ektraksi dari bagian daging (Jacoeb et al., 2015) serta dari jeroan ikan (Hastarini et al., 2012; Huli et al., 2015; Kamini et al., 2016). Ekstraksi minyak ikan dapat dilakukan dengan metode wet rendering dan dry rendering (Ahmed et al., 2017; Crexi et al., 2010). Prinsip ektraksi wet rendering adalah perebusan dan pengepresan menggunakan air sedangkan ektraksi dry rendering tidak menggunakan air untuk melepaskan minyaknya melainkan sebaliknya mengeluarkan air dari materinya (Bagus et al., 2016). Dalam penelitian ini ektraksi minyak ikan dilakukan dengan metode dry rendering, yaitu dengan cara pengukusan. Minyak ikan yang diperoleh dari ektraksi kemudian dikarakterisasi sifat fisik maupun kimiawinya. Berdasarkan keterangan di atas maka dilakukan penelitian untuk menghasilkan minyak ikan dari limbah produksi Tuna loin yakni dari kepala dan tulang ikan tuna diharapkan minyak ikan yang dihasilkan adalah omega-3 yang berguna bagi kesehatan.

Penelitian ini bertujuan untuk mengetahui kualitas fisik maupun kimiawi serta profil asam lemak minyak ikan dari kepala dan tulang ikan tuna (Thunnus albacares).

\section{METODE PENELITIAN}

\section{Bahan}

Bahan baku yang dipakai adalah kepala ikan Tuna Loin, yang diambil dari tempat penanganan 
ikan tuna loin di Desa Passo, Kecamatan Baguala, Kota Ambon. Pembuatan minyak ikan dilakukan di Laboratorium Teknologi Hasil Perikanan, Fakultas Perikanan dan Ilmu Kelautan, Universitas Pattimura Ambon. Analisis profil asam lemak di lakukan di Laboratorium Kimia Terpadu Institut Pertanian Bogor. Bahan-bahan kimia yang digunakan untuk proses preparasi dan analisa sampel adalah pure analysis.

\section{Posedur Penelitian}

\section{Preparasi Sampel Minyak Ikan}

Kepala dan tulang Ikan Tuna diperoleh dicuci bersih dan dilakukan pemisahan. Sisa-sisa daging yang ada, dipotong menjadi ukuran yang lebih kecil guna mempermudah proses ekstraksi dengan cara pengukusan (dry rendering). Ekstraksi minyak diawali dengan penimbangan sampel kepala dan tulang ikan yang telah dicacah masingmasing sebanyak $1 \mathrm{~kg}$ kemudian dimasukkan ke dalam panci pengukusan. Sampel kemudian dimasak menggunakan metode cara pengukusan selama 3 jam. Sampel yang telah dimasak dimasukkan ke dalam kain saring dan dipres. Cairan yang dihasilkan ditampung dan dilakukan dekantasi selama \pm 3 jam. Minyak kasar yang diperoleh kemudian dipisahkan dengan air yang tersisa dengan menggunakan corong pisah, mengikuti metode dimodifikasi dari Damongilala (2008). Minyak ikan kasar dari kepala dan tulang ikan tuna tersebut kemudian dimasukkan kedalam corong pisah dan dicampur dengan $60 \mathrm{~mL}$ petroleum eter (Merck, Germany) serta $25 \mathrm{~mL}$ nheksan (Merck, Germany). Campuran tersebut kemudian di kocok selama \pm 10 menit lalu didiamkan dan selanjutnya dilakukan pemisahan antara lapisan minyak dan air. Lapisan minyak yang dihasilkan kemudian diberi $\mathrm{Na}_{2} \mathrm{SO}_{4}$ (Merck, Germany) sebanyak 5-10 g untuk mengikat air yang tersisa dan selanjutnya dilakukan evaporasi terhadap lapisan minyak tersebut sehingga diperoleh minyak dari kepala dan tulang ikan tuna. Minyak ikan selanjutnya disimpan untuk dianalisis.

\section{Parameter Analisis}

Parameter yang dianalisis dalam penelitian ini meliputi rendemen, berat jenis minyak, bilangan penyabunan, bilangan iodin, bilangan tiobarbituric acid (TBA), dan profil asam lemak.

\section{Rendemen (Haris, 1983)}

Rendemen minyak di tentukan berdasarkan perbandingan antara volume minyak dengan berat bahan yang dinyatakan dalam satuan persen sehingga di peroleh perhitungan:

Rendemen minyak $(\%)=\frac{\text { minyak yang dihasilkan }}{\text { banyaknya sampel }} \times 100 \%$

\section{Berat Jenis (Haris, 1983)}

Berat jenis adalah hasil bagi dari berat benda dan juga volume benda. Adapun rumus yang di gunakan untuk menghitung berat jenis dari minyak ikan sebagai berikut:

$$
\text { Berat jenis }=\frac{\text { gram }}{\text { volume }}
$$

\section{Bilangan Iod (Metoda Wijs)}

Gliserida tak jenuh minyak mempunyai dapat menyerap sejumlah iod, ketika dibantu dengan suhu carrier seperti iodine klorida, menjadikan suatu senyawa jenuh. Jumlah iod diabsorbsi menunjukkan ketidakmajemukan minyak. Kedalam sejumlah sampel minyak/lemak ditambahkan iod (Merck, Germany) berlebih, kelebihan iod dititrasi dengan natrium tiosulfat (Merck, Germany) sehingga iod yang diabsorbsi oleh minyak/lemak dapat di ketahui jumlahnya. Prosedur analisa adalah sebagai berikut: contoh minyak ditimbang sebanyak 0,1-0,5 g ke dalam erlenmeyer bertutup. Kemudian ditambahkan 15 ml kloroform (Merck, Germany) untuk melarutkan sampel, ditambahkan juga $25 \mathrm{ml}$ pereaksi wijs dan biarkan 30 menit ditempat gelap, sambil sesekali dikocok. Larutan KI (Merck, Germany) 15\% sebanyak $20 \mathrm{~mL}$ dan $100 \mathrm{~mL}$ akuades kemudian ditambahkan. Selanjutnya adalah titrasi dengan menggunakan larutan natrium tiosulfat $0,1 \mathrm{~N}$ sampai warna kuning iod hampir hilang. Langkah selanjutnya adalah ditambahkan $2 \mathrm{~mL}$ larutan pati $1 \%$ sebagai indikator, dan dilanjutkan dengan menitrasi sehingga warna biru hilang. Dengan cara yang sama dibuat juga blanko.

Bilangan iod $=\frac{(\text { titer blanko }- \text { titer sampel })}{\text { Berat sampel }} \times N \mathrm{Na}-$ tiosulfat $\times 12,69$ 


\section{Bilangan Penyabunan (Ketaren, 1985)}

Bilangan penyabunan adalah sejumlah alkali yang dibutuhkan untuk menyabunkan sejumlah minyak. Bilangan penyabunan dinyatakan sebagai jumlah milligram $\mathrm{KOH}$ yang dibutuhkan untuk menyabunkan $1 \mathrm{~g}$ minyak/lemak. Prosedur analisanya adalah sebagai berikut: Minyak sebanyak 5 g dimasukkan dalam Erlenmeyer 300 $\mathrm{ml}$, selanjutnya ditambahkan $50 \mathrm{ml} \mathrm{KOH}$ (Merck, Germany) beralkohol. Erlenmeyer yang telah berisi contoh dan $\mathrm{KOH}$ beralkohol dihubungkan dengan pendingin tegak. Hot plate digunakan untuk mereflux contoh sampai semuanya tersabunkan, sehingga semua larutan bebas dari butiran lemak. Biasanya membutuhkan waktu 1 jam. Selanjutnya, larutan didinginkan dan bagian dalam pendingin tegak dibilas dengan akuades dan ditambahkan 1 $\mathrm{ml}$ indikator PP. Titrasi dengan $\mathrm{HCl}$ (Merck, Germany) 0,5 N hingga warna merah jambu hilang, dengan hal yang sama dibuat blanko.

$$
\text { Bilangan penyabunan }=\frac{(\text { titer blanko }- \text { titer sampel })}{\text { Berat sampel }} \times N \mathrm{HCl} 0,5 \times 56,1
$$

\section{Bilangan Tiobarbituric Acid (TBA) (Apriantono et al., 1989)}

Contoh sebanyak $10 \mathrm{~g}$ ditimbang dan dimasukkan ke dalam waring blender, kemudian ditambahkan akuades sebanyak $50 \mathrm{~mL}$ dan dihaluskan sekitar 2 menit. Secara kuantitatif contoh dipindahkan ke dalam labu destilasi, sementara itu dicuci dengan 47,5 mL akuades. Ditambahkan $\mathrm{HCl} 4 \mathrm{M}$ sebanyak 2,5 mL sampai pH menjadi 1,5, ke dalam labu destilasi ditambahkan batu didih dan pencegah buih (anti foaming agent) secukupnya.

Proses destilasi dilakukan pada suhu tinggi hingga diperoleh destilat sebanyak $50 \mathrm{~mL}$. Destilat yang diperoleh selanjutnya diaduk merata. Sebanyak $5 \mathrm{~mL}$ destilat dipipet ke dalam tabung reaksi tertutup dan ditambaahkan $5 \mathrm{~mL}$ pereaksi TBA (Merck, Germany), ditutup dan dicampur merata lalu dipanaskan selama 35 menit dalam air mendidih. Blanko dibuat dengan cara yang sama tanpa contoh menggunakan $5 \mathrm{~mL}$ akuades dan 5 $\mathrm{mL}$ pereaksi TBA.

Tabung reaksi didinginkan dengan pendinginan selama 10 menit, kemudian absorbansinya diukur (D) pada panjang gelombang $528 \mathrm{~nm}$ sebagai titik nol. Digunakan contoh sel berdiameter $1 \mathrm{~cm}$. bilangan TBA dihtung dengan cara:

$$
\mathrm{TBA}=\frac{7,8 \times \mathrm{D} \text { mg malonaldehid }}{\text { sampel }(\mathrm{kg})}
$$

\section{Profil Asam Lemak}

Analisis profil asam lemak dari minyak kepala dan tulang ikan tuna dilakukan dengan kromatografi sesuai prosedur yang dilakukan di Laboratorium Terpadu IPB Bogor dimana komposisi asam lemak ditentukan sebagai fatty acid methyl ester (FAME) dengan kromatografi gas GC QP-2010 (Shimadzu, Japan). Pembentukan FAME dari sampel didahului dengan hidrolisis dan dilanjutkan dengan esterifikasi. Sampel sebanyak 20-30 mg ditempatkan dalam tabung bertutup teflon selanjutnya ditambahkan $\mathrm{NaOH} \quad 0.5 \mathrm{~N}$ (Merck, Germany) ditambahkan sebanyak $1 \mathrm{~mL}$ dan dipanaskan dalam penangas air selama 20 menit. Ditambahkan sebanyak 2 mL BF3 16\% dan $5 \mathrm{mg} / \mathrm{mL}$ standar internal dan dipanaskan lagi selama 20 menit. Sampel tersebut kemudian didinginkan dan ditambahkan $2 \mathrm{~mL} \mathrm{NaCl}$ jenuh gas (Merck, Germany) dan $1 \mathrm{~mL}$ Heksana (Merck, Germany). Lapisan heksana tersebut kemudian dipindahkan dengan pipet tetes ke dalam tabung yang berisi $0,1 \mathrm{~g} \quad \mathrm{Na}_{2} \mathrm{SO}_{4}$ anhidrat (Merck, Germany) dan dibiarkan selama 15 menit. Fase cair sebanyak $5 \mathrm{~mL}$ sampel campuran standar FAME tersebut kemudian di injeksikan ke dalam kolom kromatografi gas. Kondisi operasional kromatografi gas: kolom kapiler (cyannopropil methyl sil), suhu Injektor $200^{\circ} \mathrm{C}$, suhu Detektor $230^{\circ} \mathrm{C}$, suhu kolom awal $190^{\circ} \mathrm{C} / 15$ menit dan akhir $230^{\circ} \mathrm{C} / 20$ menit dengan kolom flow rate $10^{\circ} \mathrm{C} /$ menit, gas pembawa $\mathrm{H}_{2}$, laju alir gas $\mathrm{H}_{2} 30$ $\mathrm{mL} / \mathrm{menit}$ gas $\mathrm{N}_{2} 20 \mathrm{~mL} / \mathrm{menit}$, laju alir udara 200-250 mL/menit (Panagan et al., 2012).

\section{Analisis Data}

Data hasil penelitian ini dianalisa secara deskriptif, dimana hasil yang diperoleh disajikan dalam bentuk tabel dan histogram.

\section{HASIL DAN PEMBAHASAN}

\section{Karakteristik Fisika dan Kimia Minyak Dari Kepala dan Tulang Ikan Tuna}

Hasil analisis karakteristik fisik (rendemen dan berat jenis minyak) dan karakteristik kimia yaitu bilangan asam, iod, penyabunan dan nilai TBA dari minyak ikan yang berasal dari kepala dan tulang ikan tuna ditunjukkan pada Gambar 1 dan 2 . 


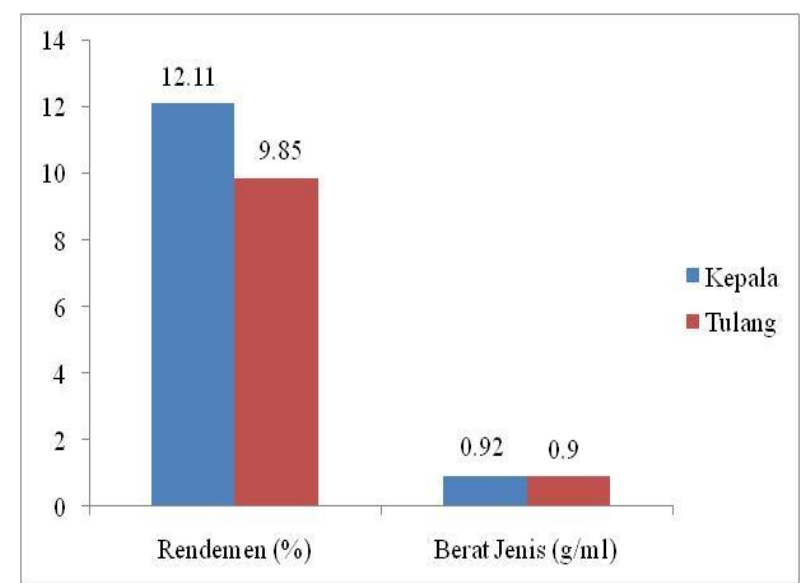

Gambar 1. Rendemen dan berat jenis minyak ikan tuna

Rendemen minyak dari kepala dan tulang ikan tuna (Gambar 1) masing-masing adalah sebesar $12,11 \%$ dan $9,85 \%$. Rendemen merupakan presentase bahan baku utama yang bisa dijadikan produk akhir atau perbandingan produk akhir dengan bahan baku utamanya. Semakin tinggi rendemen berarti bagian minyak yang dihasilkan semakin banyak. Kualitas minyak hasil proses ekstraksi yang dihasilkan umumnya berbanding terbalik dengan presentasi rendemen. Defandi (2015) melaporkan rendemen minyak ikan dari bagian kepala ikan tuna adalah sebesar 30,13\%, sedangkan Istiqlaal (2018) melaporkan bahwa rendemen minyak ikan tulang ikan tuna adalah sebesar 25,23-38,80\%. Rendemen minyak yang dihasilkan dalam penelitian ini jauh lebih rendah bila dibandingkan dengan hasil kedua peneliti sebelumnya. Perbedaan ini dapat disebabkan karena kadar lemak ikan yang digunakan. Semakin tinggi kadar lemak ikan maka akan meningkatkan jumlah minyak ikan yang dihasilkan. Apituley (2009) menyatakan kadar lemak ikan tuna (Thunus sp.) adalah sebesar 2,16\% lebih tinggi dari kadar lemak ikan yellowfin tuna sebesar 1,93\% dan big eye tuna sebesar 2,06\% (Pheng et al., 2013). Aditia et al. (2014) melaporkan rendemen minyak ikan tongkol lebih rendah bila dibandingkan dengan rendemen minyak ikan lele dan bandeng karena kandungan lemak ikan lele dan bandeng juga lebih tinggi dari kadar lemak ikan tongkol. Selain itu perbedaan metode ekstraksi yang digunakan serta perlakuan tambahan yang diberikan juga sangat berpengaruh pada rendemen yang dihasilkan. Defandi (2015) melakukan ekstraksi minyak dengan metode Soxhlet (yaitu menggunakan pelarut $\mathrm{n}$-heksan) yang disertai dengan freezedrying yang bertujuan untuk menghilangkan kadar air yang membuat rendemen minyak ikan yang dihasilkannya lebih tinggi yaitu $16,53 \%$.

Berat jenis atau densitas minyak ikan dari kepala dan tulang ikan tuna (Gambar 1) masingmasing sebesar $0,92 \mathrm{~g} / \mathrm{mL}$ dan $0,90 \mathrm{~g} / \mathrm{mL}$. Berat jenis atau densitas minyak ikan yang dihasilkan dalam penlitian ini tidak jauh berbeda dengan hasil penelitian Defandi (2015) yaitu kisaran 0,91-0,95 $\mathrm{g} / \mathrm{mL}$. Berat jenis atau densitas minyak ikan tidak hanya dipengaruhi oleh metode ekstraksinya, bagian tubuh sumber minyak yang diekstraksi dan bilangan penyabunan. Minyak dengan komposisi asam lemak berantai karbon pendek akan memiliki berat molekul yang relatif lebih kecil dan akan mempunyai nilai angka penyabunan yang besar. Sebaliknya minyak dengan berat molekul yang besar akan memiiliki nilai angka penyabunan yang realtif lebih kecil (Istiqlaal, 2018).

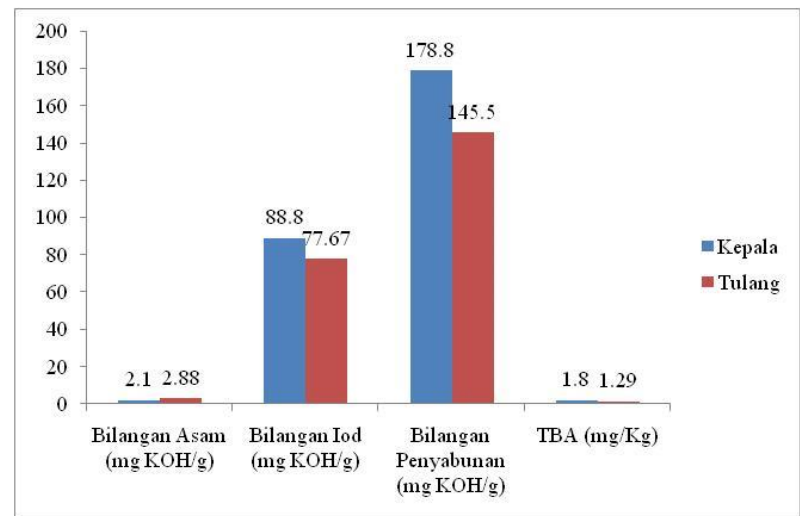

Gambar 2. Karakteristik kimia minyak dari kepala dan tulang ikan tuna

Karakteristik kimia minyak ikan tuna meliputi bilangan asam, bilangan iod, bilangan penyabunan dan TBA ditunjuk pada Gambar 2. Nilai bilangan asam minyak ikan yang berasal dari kepala dan tulang ikan tuna masing-masing sebesar $2.10 \mathrm{mg} \mathrm{KOH} / \mathrm{g}$ dan 2,88 mg KOH/g. Rozi et al. (2016) menyatakan nilai bilangan asam berkaitan erat dengan jumlah $\mathrm{KOH}$ yang digunakan untuk menetralkan $1 \mathrm{~g}$ minyak. Bilangan asam juga memiliki keterkaitan yang erat dengan nilai asam lemak bebas dimana nilai bilangan asam diperoleh dengan perkalian konstanta 1,99 dengan nilai asam lemak bebas. Nilai asam lemak bebas menunjukkan kandungan asam lemak yang tidak dalam bentuk trigliserida. Nilai asam lemak bebas ini merupakan salah satu parameter dalam menentukan kualitas minyak, dimana semakin besar nilai asam lemak bebas suatu minyak maka semakin tidak baik kualitas minyak tersebut. Keberadaan air selama proses ekstraksi dapat 
menyebabkan terjadinya hidrolisis pada asam lemak sehingga terlepas dari kerangka gliserol (Estiasih et al., 2009). Hasil penelitian menunjukkan nilai bilangan asam yang lebih tinggi bila dibandingkan dengan hasil penelitian dari Ngadiarti et al. (2013) yang berada pada kisaran 0,06-0,14 mg KOH/g namun sedikit lebih rendah bila dibandingkan dengan nilai bilangan asam minyak tulang ikan hasil penelitian dari Istiqlaal (2018) yang berada pada kisaran 4,32-5,88 mg $\mathrm{KOH} / \mathrm{g}$. Nilai bilangan asam minyak kepala dan tulang ikan tuna yang dihasilkan dalam ini masih berada dalam kisaran standar mutu dari IFOS (2011) yaitu maksimal sebesar 2,25 mg KOH/g dan SNI maksimal sebesar $3 \mathrm{mg} \mathrm{KOH} / \mathrm{g}$ (Istiqlaal, 2018).

Nilai bilangan Iod minyak ikan kepala dan tulang ikan tuna masing-masing sebesar 88,80 mg $\mathrm{KOH} / \mathrm{g}$ dan 77,67 mg KOH/g. Ketaren (2005) menyatakan bahwa bilangan iod adalah jumlah (gram) iod yang dapat diikat oleh $100 \mathrm{~g}$ lemak. Kandungan asam lemak tidak jenuh yang tinggi dari minyak ikan akan mengikat Iod dalam jumlah yang lebih banyak, karena itu bilangan Iod sering digunakan sebagai ukuran dari ketidakjenuhan suatu minyak dan lemak. Minyak dengan bilangan Iod yang tinggi cenderung akan berada dalam wujud cair. Minyak kepala dan tulang ikan tuna dalam penelitian ini berada dalam wujud cair yang mengindikasikan adanya asam lemak jenuh yang tinggi. Minyak dengan kandungan Poly Unsaturated Fatty Acid (PUFA) yang tinggi seperti yang ditemukan dalam penelitian ini akan cenderung berada dalam wujud cair pada suhu ruangan bahkan tetap cair bila berada pada suhu dingin karena memiliki titik leleh yang rendah bila dibandingkan dengan dengan Mono Unsaturated Fatty Acid (MUFA) atau Saturated Fatty Acid (SFA). Bilangan Iod minyak ikan dari kepala dan tulang ikan tuna dalam penelitian ini lebih rendah bilang dibandingkan dengan yang dihasilkan dari hasil penelitian Defandi (2015) yakni sebesar 102,78 mg KOH/g untuk minyak kepala ikan dan 87,15 untuk minyak tulang ikan, namun lebih tinggi bila dibandingkan dengan hasil penelitian Nugroho et al. (2014) yang berada pada kisaran 56,6-73,5 mg $\mathrm{KOH} / \mathrm{g}$ untuk minyak ikan Nila.

Nilai bilangan Penyabunan dari minyak kepala dan tulang ikan tuna masing-masing sebesar $178,80 \mathrm{mg} \mathrm{KOH} / \mathrm{g}$ dan $145,50 \mathrm{mg} \mathrm{KOH} / \mathrm{g}$. Menurut Panagan et al. (2011), besar atau kecilnya angka penyabunan menunjukkan besar kecilnya berat molekul asam lemak yang terkandung dalam minyak. Minyak yang dengan asam lemak berantai C pendek, akan memiliki berat molukul yang kecil. Berat molekul semakin kecil menyebabkan angka penyabunan semakin besar. Raharja et al. (2011) menyatakan bahwa semakin tinggi bilangan penyabunan maka semakin baik mutu minyak tersebut. Hal ini disebabkan karena semakin pendek rantai karbon maka asam lemak akan lebih mudah dimetabolisir tubuh, sebaliknya bila memiliki rantai karbon yang panjang maka minyak tersebut hanya bisa dicerna oleh enzim lipase dengan bantuan asam empedu. Nilai bilangan penyabunan minyak kepala dan tulang ikan tuna dalam penelitian ini lebih rendah bila dibandingkan dengan nilai bilangan penyabunan minyak ikan lemuru dari hasil penelitian Raharja et al. (2011) yakni sebesar 187,4 mg KOH/g.

Nilai TBA dari minyak kepala dan tulang ikan tuna masing-masing sebesar $1,80 \mathrm{mg} / \mathrm{kg}$ dan $1,29 \mathrm{mg} / \mathrm{kg}$. Angka TBA seringkali digunakan untuk mengukur produk sekunder dari oksidasi lipida terutama yang berasal dari PUFA dan menunjukkan tingkat ketengikan khususnya pada minyak atau lemak dengan kandungan PUFA yang tinggi (Cheng et al., 2014; Semb, 2012). Bilangan TBA dalam penelitian ini menunjukan bahwa selama proses produksi minyak dari kepala dan tulang ikan tidak dapat dihindari terjadinya oksidasi secara mutlak selama proses tersebut berlangsung, akan tetapi nilai TBA yang dihasilkan masih berada dalam standar yang ditetapkan oleh International Fish Oil Manufacturer Association yakni sebesar 3-20 meq/1000 g.

\section{Profil Asam Lemak Minyak Ikan Dari Kepala dan Tulang Ikan Tuna}

Profil asam lemak minyak dari kepala dan tulang ikan ikan Tuna dengan menggunakan gas kromatografi dapat di lihat pada Tabel 1 dan Gambar 3. Hasil penelitian pada Tabel 1 menunjukkan bahwa asam lemak tidak jenuh mendominasi minyak dari kepala maupun tulang ikan Tuna. Minyak ikan dari kepala ikan tuna mengandung 25 jenis asam lemak terdiri dari 10 jenis asam lemak jenuh SFA 20,8\% w/w, tujuh jenis lemak tak jenuh tunggal MUFA 11,92\% w/w, 8 asam lemak tak jenuh jamak PUFA 35,98\% w/w; sedangkan pada minyak dari tulang ikan Tuna mengandung 26 jenis asam lemak terdiri dari 11 asam lemak jenuh SFA 19,69\% w/w, tujuh asam lemak tak jenuh tunggal MUFA $10,80 \%$ w/w, dan delapan asam lemak tak jenuh jamak PUFA $26,21 \% \mathrm{w} / \mathrm{w}$. 
Tabel 1. Profil asam lemak minyak dari kepala dan tulang ikan tuna

\begin{tabular}{|c|c|c|}
\hline Komposisi asam lemak & $\begin{array}{c}\text { Minyak Kepala Ikan } \\
(\% \mathrm{w} / \mathrm{w})\end{array}$ & $\begin{array}{c}\text { Minyak Tulang Ikan } \\
(\% \mathrm{w} / \mathrm{w})\end{array}$ \\
\hline \multicolumn{3}{|l|}{ Asam Lemak Jenuh (Saturatet Fatty Acid/SFA) } \\
\hline Asam Laurat (C120) & nd & 0.22 \\
\hline Asam Miristat $(\mathrm{C} 14: 0)$ & 1.52 & 1.66 \\
\hline Asam Pentadekanoat (C15:0) & 0.47 & 0.48 \\
\hline Asam Palmitat (C16:0) & 13.13 & 12.35 \\
\hline Asam Heptadekanoat (C17:0) & 0.80 & 0.78 \\
\hline Asam Stearat (C18:0) & 4.17 & 3.82 \\
\hline Asam Arakidat (C20:0) & 0.27 & 0.24 \\
\hline Asam Heneikosanoat (C21:0) & 0.06 & 0.05 \\
\hline Asam Behenat (C22:0) & 0.17 & 0.13 \\
\hline Asam Trikosanoat (C23:0) & 0.06 & 0.05 \\
\hline Asam Lignoserat (C24:0) & 0.16 & 0.11 \\
\hline Total SFA & 20.8 & 19.69 \\
\hline \multicolumn{3}{|c|}{ Asam Lemak Tak Jenuh Tunggal (Monounsaturated Fatty Acid/MUFA) } \\
\hline Asam Miristoleat $(\mathrm{C} 14: 1)$ & 0.02 & 0.02 \\
\hline Asam Palmitoleat (C16:1) & 2.91 & 2.64 \\
\hline Cis-10,-Heptadekanoat (C17:1) & 0.10 & 0.36 \\
\hline Asam Elaidat $(\mathrm{C} 18: 1 \mathrm{n} 9 \mathrm{t})$ & 0.10 & 0.09 \\
\hline Asam Oleat (C18:1n9c) & 7.90 & 7.04 \\
\hline Cis-11-Eikosanoat (C20:1) & 0.58 & 0.50 \\
\hline Asam Nervonat (C24:1) & 0.31 & 0.23 \\
\hline Total MUFA & $\mathbf{1 1 . 9 2}$ & $\mathbf{1 0 . 8 0}$ \\
\hline \multicolumn{3}{|c|}{ Asam Lemak Tak Jenuh Jamak (Polyunsaturated Fatty Acid/PUFA ) } \\
\hline Asam Linoleat $(\mathrm{C} 18: 2 \mathrm{n} 6 \mathrm{c})$ & 0.84 & 0.90 \\
\hline Y-Linolenat (C18:3n6) & 0.09 & 0.07 \\
\hline Asam Linoleat (C18:3n3) & 0.36 & 0.31 \\
\hline Cis-11,14-Eikosadienoat (C20:2) & 0.20 & 0.16 \\
\hline Cis-8,11,14,-Eikosatrienoat (C20:3n6) & 0.12 & 0.10 \\
\hline Asam Arakhidonat (C20:4n6) & 2.19 & 1.73 \\
\hline Cis-5,8,11,14,17-EPA (C20:5n3) & 4.85 & 3.70 \\
\hline Cis-4,7,10,13,16,19-DHA (C22:6n3) & 27.33 & 19.24 \\
\hline Total PUFA & 35.98 & 26.21 \\
\hline
\end{tabular}

Hasil penelitian menunjukkan minyak dari kepala maupun tulang ikan tuna mengandung asam lemak jenuh lebih rendah daripada kandungan asam lemak tidak jenuhnya. Asam lemak jenuh dari minyak kepala dan tulang ikan Tuna di dominasi oleh asam palmitat (C16:0) masingmasing sebesar $13,13 \%$ dan $12,35 \%$ serta asam stearat (C18:0) masing-masing sebesar 4,17\% dan $3,82 \%$. Minarny et al. (2014) menyatakan bahwa ikan tuna mengandung palmitat sebesar 32,60\%. Ferdosh et al. (2014) menyatakan bahwa sebagian besar Asam lemak tidak jenuh pada ikan tongkol (Euthynus affinis maupun Auxis thazard) didominasi oleh asam palmitat. Sedangkan asam lemak tidak jenuh dari minyak kepala dan tulang ikan Tuna dengan jumlah yang cukup besar diantaranya adalah asam oleat (C18:1n9) sebesar $7,90 \%$ untuk minyak dari kepala ikan Tuna dan $7,04 \%$. untuk minyak tulang ikan Tuna. Asam arakidonat (C20:4n6) masing-masing sebesar 2,19\% dan 1,73\%. EPA (C20:5n3) masing-masing sebesar 4,85\% dan 3,70\% serta DHA (C22:6n3) masing-masing sebesar 27,33\% dan 19,24\%. Hasil serupa juga di kemukakan oleh Mahaliyana et al. (2015) yang menemukan bahwa komponen DHA minyak ikan Skipjack tuna (cakalang) sebesar $35,66 \%$ lebih tinggi dibanding EPA sebesar 4,74\%. Renuka et al. (2016) juga menemukan kandungan lemak ikan Tuna juga di dominasi oleh DHA yakni sebesar 36,2\% dan Rasmussen et al. (2008) menyatakan kandungan DHA ikan Tuna adalah sebesar $33,80 \%$. Asam lemak tak jenuh jamak 
PUFA-n3 pada ikan terutama EPA dan DHA merupakan asam lemak yang banyak diteliti karena manfaatnya untuk mencegah penyakit-penyakit yang berhubungan dengan pembuluh darah. Sedangkan asam arakhidonat merupakan asam lemak tak jenuh jamak PUFA-n6 yang juga diperlukan untuk pertumbuhan dan perkembangan otak serta berperan penting dalam menjaga kekencangan kulit manusia (Almatsier, 2002). Adanya asam lemak omega 3 seperti EPA (C20:5n3) serta DHA (C22:6n3) menunjukkan tingginya kualitas nutrisi minyak dari kepala dan tulang ikan Tuna. Menurut Shahidi (1998), adanya asam lemak rantai panjang PUFA seperti EPA dan DHA menunjukkan keunikan serta ciri khas yang membedakan lemak hewan laut dengan lemak hewan darat pada umumnya. Keberadaan PUFA tersebut sangat penting dalam pencegahan dan pengobatan penyakit kardiovaskuler, hipertensi (Meyer et al., 2003).

Profil asam lemak tak jenuh jamak PUFAn3 dan PUFA- n6 minyak dari kepala dan tulang ikan Tuna dapat di lihat pada Gambar 3, dimana terlihat bahwa kandungan PUFA-n3 dan PUFA-n6 dari minyak kepala ikan Tuna masing-masing sebesar $35,83 \%$ dan 32,42\% lebih tinggi dari kandungan PUFA- n3 dan PUFA-n6 minyak tulang ikan tuna masing-masing sebesar 25,98\% dan $23,05 \%$. Hal ini juga terlihat dari rasio PUFAn3/PUFA-n6 seperti yang terlihat pada Gambar 3. Rasio PUFA-n3/PUFA-n6 minyak kepala ikan Tuna 3,21\% lebih tinggi dari rasio PUFAn3/PUFA-n6 minyak tulang ikan Tuna 2,27\%. Tingginya rasio PUFA-n3/PUFA-n6 tersebut menunjukkan bahwa kualitas minyak dari kepala ikan Tuna lebih baik bila dibandingkan dengan kualitas lemak dari minyak tulang ikan Tuna.

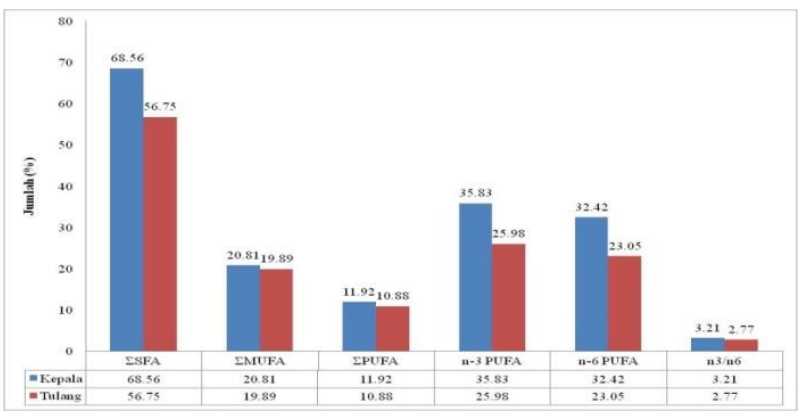

Gambar 3. Kandungan asam lemak jenuh, tidak jenuh serta profil asam lemak omega 3 dan omega 6 dari minyak kepala dan tulang ikan tuna

\section{KESIMPULAN}

Karakteristik fisik yakni rendemen minyak dari kepala dan tulang ikan masing-masing sebesar 12,11 dan 9,85\% dengan berat jenis masingmasing sebesar $0,92 \mathrm{mg} / \mathrm{mL}$ dan $0,90 \mathrm{mg} / \mathrm{mL}$. Sedangkan karakteristik kimia seperti bilangan asam, iod dan penyabunan serta TBA dari minyak dari kepala dan tulang ikan tuna masing-masing sebesar 2,10 $\mathrm{mg} \mathrm{KOH} / \mathrm{g}$ dan 2,88 mg KOH/g; 88,80 mg KOH/g dan 77,67 $\mathrm{mg} \mathrm{KOH} / \mathrm{g}$; $178,80 \mathrm{mg} \mathrm{KOH} / \mathrm{g}$ dan $145,50 \mathrm{mg} \mathrm{KOH} / \mathrm{g}$ serta $1,80 \mathrm{mg} / \mathrm{kg}$ dan 1,29 $\mathrm{mg} / \mathrm{Kg}$.

Asam lemak tidak jenuh mendominasi minyak dari kepala maupun tulang ikan Tuna. Minyak ikan dari kepala ikan tuna mengandung 25 jenis asam lemak terdiri dari 10 jenis SFA 20,8\% w/w, tujuh jenis MUFA 11,92\% w/w, 8 PUFA $35,98 \%$ w/w; sedangkan pada minyak dari tulang ikan Tuna mengandung 26 jenis asam lemak terdiri dari 11 asam lemak jenuh SFA 19,69\% w/w, tujuh tunggal MUFA $10,80 \% \mathrm{w} / \mathrm{w}$, dan delapan PUFA $26,21 \% \mathrm{w} / \mathrm{w}$.

Kandungan PUFA-n3 dan PUFA-n6 dari minyak kepala ikan Tuna masing-masing sebesar $35,83 \%$ dan 32,42\%, sedangkan kandungan PUFA-n3 dan PUFA-n6 minyak tulang ikan tuna masing-masing sebesar $25,98 \%$ dan $23.05 \%$. Rasio PUFA-n3/PUFA-n6 minyak kepala ikan Tuna 3,21\% lebih tinggi dari rasio PUFA-n3/PUFA-n6 minyak tulang ikan Tuna 2,27\%. Tingginya rasio PUFA-n3/PUFA-n6 tersebut menunjukkan bahwa kualitas minyak dari kepala ikan Tuna lebih baik bila dibandingkan dengan kualitas lemak dari minyak tulang ikan Tuna.

\section{UCAPAN TERIMA KASIH}

Ucapan terima disampaikan kepada Dekan Fakultas Perikanan dan Ilmu Kelautan Universitas Pattimura yang telah mendanai penelitian ini melalui dana PNBP Universitas Pattimura.

\section{DAFTAR PUSTAKA}

Almatsier. 2002. Prinsip Dasar Ilmu Gizi. Gramedia Pustaka Utama. Jakarta

Aditia, R.P., Y.S. Darmanto, dan Romadhon. 2014. Perbandingan mutu minyak ikan kasar yang diekstrak dari berbagai jenis ikan yang berbeda. Jurnal Pengolahan dan Bioteknologi Hasil Perikanan 3: 55-60.

Ahmed, R., M. Haq, Y. Cho, and B.S. Chun. 2017. Quality evaluation of oil recovered from by- 
products of bigeye tuna using supercritical carbon dioxide extraction. Turkish Journal of Fisheries and Aquatic 17: 663-672. DOI: 10.4194/1303-2712-v17_4_02.

Apituley, D.A.N. 2009. Pengaruh penggunaan formalin terhadap kerusakan protein daging ikan Tuna (Thunus sp.). Agritech 29: 22-28.

Bagus. E., Junianto, dan E. Rochima. 2016. Pengaruh metode rendering terhadap karakteristik fisik, kimia dan organoleptik ekstrak kasar minyak ikan lele. Jurnal Perikanan Kelautan 7: 1-5.

Cheng, J.H., D.W. Sun, H.B. Pu, Q.J. Wang, and Y.N. Chen. 2014. Suitability of hyperspectral imaging for rapid evaluation of thiobarbituric acid (TBA) value in grass carp (Ctenopharyngodon idella) fillet. Food Chemistry 171: 258-265. DOI: 10.1016/j.foodchem.2014.08.124

Crexi, V.T., M.L. Monte, L.A.D. Soares, and L.A.A. Pinto. 2010. Production and refinement of oil from carp (Cyprinus carpio) viscera. Journal of Food Chemistry 119: $\quad 945-950 . \quad$ DOI: $\quad 10.1016$ /j.foodchem.2009.07.050.

Damongilala, L.J. 2008. Kandungan asam lemak tak-jenuh minyak hati ikan cucut botol (Cenctrophorus sp.) yang diekstrak dengan cara pemanasan. Jurnal Ilmiah Sains 8: 249253.

Defandi, F., 2015. Sifat Fisiko Kimia Minyak Ikan dari Limbah Pengolahan Ikan Tuna (Thunnus sp). Skripsi. Fakultas Teknologi Pertanian, Universitas Andalas, Padang.

Estiasih, T., K. Ahmadi, F. Choirun, dan F. Kusumastuti. 2009. Optimasi kondisi pemurnian asam lemak omega-3 dari minyak hasil samping penepungan tuna (Thunnus sp.) dengan kristalisasi urea. Jurnal Teknologi dan Industri Pangan 20: 135-142.

Ferdosh, S., Z.I. Sarker, N. Norulaini, A. Oliveira, K. Yunus, A.J. Chowdury, J. Akanda, and M. Omar. 2014. Quality of Tuna Fish oils extracted from processing th bye-products of three species of neritic tuna using supercritical carbon dioxide. Journal of Food Processing and Preservation 39: 432441. DOI: $10.1111 /$ jfpp. 12248

Hastarini, E., D. Fardiaz, H.E. Irianto, dan S. Budijanto. 2012. Karakteristik minyak ikan dari limbah pengolahan filet ikan patin siam (Pangasius hhypopthalmus) dan patin jambal (Pangasius djambal). Agritech 32: 403-410. DOI: 10.22146/agritech.9584

Haris, R. 1983. Minyak Ikan. Jakarta. Penebar Swadaya.

Huli, L.O., S.H. Suseno, dan J. Santoso. 2014. Kualitas minyak ikan dari kulit ikan swangi Jurnal Pengolahan Hasil Perikanan Indonesia 17: 233-242. DOI: 10.17844/jphpi.v17i3.8912

[IFOS] International Fish Oil Standard. 2014. Fish Oil Purity Standards. www.omegavia. com/best [3 Februari 2018].

Istiqlaal, S. 2018. Esktraksi dan karakteristik minyak tulang ikan tuna. JPB Kelautan dan Perikanan 13: 141-1252.

Jacoeb, A.M., P. Suptijah, dan P.A. Kristantina. 2015. Komposisi asam lemak, kolesterol dan deskripsi jaringan fillet ikan kakap merah segar dan goreng. Jurnal Pengolahan Hasil Perikanan Indonesia 18: 99-107.

Jung, W.K., P.J. Park, H.G. Byun, S.H. Moon, and S.K. Kim. 2005. Preparation of hoki (Johnius belengerii) bone oligophosphopeptide with a high affinity to calcium by carnivorous intestine crude proteinase. Food Chemistry 91: 333-340. DOI: 10.1016/j.foodchem.2004.06.016

Kamini, P. Suptijah, J. Santoso, dan S.H. Suseno. 2016. Ekstraksi dry rendering dan karakterisasi minyak ikan dari lemak jeroan hasil samping pengolahan salai patin siam. Jurnal Pengolahan Hasil Perikanan Indonesia 19: 196-205. DOI: 10.17844/jphpi.v19i3.15071.

Kantun W., A. Mallawa, dan N.L. Rapi. 2014. Struktur ukuran dan jumlah tangkapa tuna madidihang Thunnus albacares menurut waktu penangkapan dan kedalaman di Perairan Majene Selat Makassar. Jurnal Saintek Perikanan 9: 39-48.

Ketaren, S. 2005. Pengantar Teknologi Minyak dan Lemak Pangan. UI Press : Jakarta.

KKP. 2015. Statistik Perikanan Tangkap Menurut Provinsi 2015. Jakarta (ID): Kementerian Kelautan dan Perikanan.

Mahaliyana, A.S., B.K.K.K. Jinadasa, N.P.P. Liyanage, G.D.T.M. Jayasinghe, and S.C. Jayamannel. 2015. Nutritional composition of skipjack tuna (Katsuwonus pelamis) caught from the Oceanic Waters around Sri Lankae. American Journal of Food and Nutrition 3: 106-111. DOI: 10.12691/ajfn-34-3 
Meyer, B.J., N.J. Mann, J.L. Lewis, G.C. Milligan, A.J. Sinclair, and P.R. Howe. 2003. Dietary intakes and food sources of omega- 6 and omega-3 polyunsaturated fatty acids. Lipids 38: 391-398. DOI: 10.1007/s11745003-1074-0

Minarny, G., H. Purnomo, Asriani, and D. Rosyidi. 2014. Fatty acid profile of fish central Sulawesi Indonesia. International Food Research Journal 21: 979-983.

Ngadiarti, I., C.M. Kusharto, D. Briawan, S.A. Marliyati, dan D. Sayuthi. 2013. Kandungan asam lemak dan karakteristik fisikokimia minyak ikan lele dan minyak ikan lele terfermentasi. Penelitian Gizi dan Makanan 36: 82-90. DOI: 10.22435/pgm.v36i1.3398.82-90

Nugroho, A.J., R. Ibrahim, dan P.H. Riyadi. 2014. Pengaruh perbedaan suhu pengukusan terhadap kualitas minyak dari limbah usus ikan nila. Jurnal Pengolahan dan Bioteknologi Hasil Perikanan 3: 21-29.

Panagan, A.T., H. Yohandini, dan U.J. Gultom. 2011. Analisa kualitatif dan kuantitatif asam lemak tak jenuh omega-3 dari minyak ikan patin (Pangasius pangasius) dengan metoda kromatografi. Jurnal Penelitian Sains 14: 38-42.

Panagan, A.T., H. Yohandini, dan M. Wulandari. 2012. Analisis kualitatif dan kuantitatif asam lemak tak jenuh omega-3, omega-6 dan karakterisasi minyak ikan patin (Pangasius pangasius). Jurnal Penelitian Sains 15: 102106.

Pheng, S., C. Chen, S. Zhaohong, and L. Wangi. 2013. Amino acid and fatty acid composition of the muscle tissue of yellowfin tuna (Thunnus albacares) and bigeye tuna (Thunnus obesus). Journal of Food and Nutrition Research 1: 42-45. DOI: 10.12691/jfnr-1-4-2

Purwaningsih, S., E. Salamah, dan Dewantoro. 2014. Komposisi kimia dan asam lemak ikan glodok akibat pengolahan suhu tinggi. Jurnal Pengolahan Hasil Perikanan Indonesia 17: 165-174. DOI: 10.17844/jphpi.v17i2.8720

Raharja, S., P. Suryadarma, dan T. Oktavia. 2011. Hidrolisis enzimatik minyak ikan untuk produksi asam lemak omega-3 menggunakan lipase dari Aspergillus niger. Jurnal Teknologi dan Industri Pangan 22: 64-72.

Rassmussen, H.E., K.R. Blobaum, and Y.K. Park. 2008. Lipid extract of Nostoc commune var. Spaevoides Kutzing. Journal of Nutrition 138: 476-481

Renuka, V., R. Anandan, M. Suseela, C.N. Ravishankar, and G.K. Sivaraman. 2016. Fatty acid profile of yellowfin tuna eye (Thunnus albacares) and oil sardine muscle (Sardinella longiceps). Fishery Technology 53: 151-154.

Rozi, A., S.H. Suseno, dan A.M. Jacoeb. 2016. Ekstrak dan karakterisasi minyak hati cucut pisang. Jurnal Pengolahan Hasil Perikanan Indonesia 19: 100-109.

Sarker, M.Z.I., J. Selamat, A.S.M.A. Habib, S. Ferdosh, M.J.H. Akanda, and J.M. Jaffri. 2012. Optimization of supercritical $\mathrm{CO}_{2}$ extraction of fish oil from viscera of african catfish (Clarias gariepinus). International Journal of Molecular Sciences 13: 1131211322. DOI: 10.3390/ijms130911312

Semb, T.N. 2012. Analitycal Methods for Determination of The Oxidative Status in Oils. Department of Biotechnology, Norwegian University of Science and Technology.

Shahidi, F. 1998. Functional seafood lipids and proteins. In: Functional foods, Biochemical and Processing Aspects. Mazza, G. (Ed). Technomic Publishing Company Inc. Lancaster P.A. pp. 381-390. 